\title{
What are the aims of the implementation of e-solutions in healthcare? Review of the relevant practical studies
}

\section{Tadeusz Władysław Jędrzejczyk ${ }^{1} \stackrel{\odot}{ }$, Marzena Zarzeczna-Baran²}

\author{
${ }^{1}$ Medical University of Gdańsk, Poland \\ ${ }^{2}$ Department of Public Health \& Social Medicine, Medical University of Gdańsk, Poland
}

\begin{abstract}
The eHealth solutions are an effect of applying new technologies (ICT) in health care. The phenomenon is commonly described as transformation of the healthcare system as its influence on management and organization of care is both wide and deep. This review concentrate on aims of practical research along with an attempt to present useful stratification. The result of the study reveals that it is usually more than one goal of most of reviewed research. This lead to conclusion that the very early stage of research on eHealth should be based on picking its aims and relationship between them.

Keywords: aim • mHealth • eHealth • study design • healthcare value
\end{abstract}

\section{Citation}

Jędrzejczyk TW, Zarzeczna-Baran M. What are the aims of the implementation of e-solutions in healthcare? Review of the literature. Eur J Transl Clin Med. 2019;2(1):78-84.

DOI: $10.31373 /$ ejtcm/104720

\section{Introduction}

The development of medical science has been always related to the progress of other technological and scientific discoveries. Computer sciences, tele- communication and electronic inventions were developed parallel to new medical procedures. EHealth (defined as medicine supported by electronic processes and communication tools), mobile health (mhealth, supported by mobile technology), ICT (information

Corresponding author:

Tadeusz Jędrzejczyk, Medical University of Gdańsk

e-mail: tadeusz.jedrzejczyk@gumed.edu.p

No external funds.

Available online: www.ejtcm.gumed.edu.pl

Copyright $®$ Medical University of Gdańsk

This is Open Access article distributed under the terms of the Creative Commons Attribution-ShareAlike 4.0 International. 
and communication technology) and telemedicine technologies are not merely new fashionable concepts but the tools which are increasingly used in healthcare since the late 1970s. These technologies goes along with the way how medical services are provided. Practitioners and researchers pointed some benefits which are related to technological development in their field. These improvements require a great expenses as well as scientific involvement by healthcare providers and governmental agencies. Public spending spurs new technology which nonetheless requires an evaluation of the outcomes. As long as 30 years ago the European Commission started to support eHealth initiatives, providing around 500 million euro for approximately 400 projects between 1988 and 2003 [1]. Investment in eHealth is still increasing, with 197.5 million euro are to be spent in years 2018-2020 [2].

Although the above-described are only complementary to the basic healthcare functions (prevention, diagnosis, treatment and rehabilitation), the impact of eHealth on the organization of medical services is substantial. The exact assessment of the impact of a given eHealth solution on actual improvement requires deployment of adequate methodological tools. The complete research process on eHealth and telemedicine consists of five stages: concept development, service design, pre-implementation, implementation and post-implementation analysis [3]. The contemporary knowledge upon eHealth use needs systematic evaluation.

\section{Material and methods}

Google Scholar database was Boolean searched with various of keywords combination: "eHealth", "research", "effectiveness", "healthcare", "study" "patient", "value", "project", "data", "disease". E-scholar database was chosen due to its unique characteristic, including multidisciplinary and widely open for diversified editors, direct open access of the full-text of numerous articles. Studies published since 2015 were screened. The top most five cited articles were selected from every search for further evaluation (synthesis), taking into account how long given article was accessible. The inclusion criteria were as follows: clinical trials, cases reports and reviews of original trials. The extraction of the declared aim and methodological approach was performed than the process of aggregation into broader categories was performed. The complete review of articles was presented together with the specific application of given study.

\section{Results}

Following study search and selection, 28 articles were included in the review synthesis. The selection process revealed a broad spectrum of interest among eHealth of their authors. The aims of studies were identified, the results of review were presented according to the area of interest.

Out of 28 studies, 15 (53.6\%) had 1 specific research aim, $8(28.6 \%)$ had 2 aims and 5 (17.8\%) were designed to find out 3 aims. The most popular research question was healthcare effectiveness. The definition of "healthcare" was defined very broadly in the reviewed articles, including health promotion, education, diagnosis, treatment and rehabilitation. Secondly, articles focused on patients' perception and attitude towards new technological solutions in healthcare delivery. The $3^{\text {rd }}$ and $4^{\text {th }}$ goals of the analyzed articles were professional perceptions of eHealth solutions and improving their quality through better data collection and aggregation. On the other hand, only 1 paper focused on the safety of the patients' care. Along with the identification of the aims of the studies we paid attention on what kind of research was undertaken to present it in the given article. The most common was qualitative study while randomised controlled trials were rare way to study the phenomenon of eHealth.

\section{Discussion}

\section{Health education and promotion}

The development of internet continues to bring an exponential increase in information including health promotion. Furthermore, it is challenging for the reader to verify the quality and accuracy of the available data. Therefore, granting public access to seemingly valuable information is not an efficient way to increase awareness of health risks or to support individuals in making healthy choices. Thus it is not surprising that one of the principal aims of eHealth studies is assessing the actual response to the delivered information [6, 13].

\section{Early diagnosis - interviews}

Web questionnaires are a useful and time-saving tool to gather information from patients and thus support and shorten the actual face-to-face interview. This can be applied on the level of provider and improve communication with patients before their scheduled appointments. Moreover, online surveys could target larger group of individuals. A few studies aimed at improving the quality of such tools [19]. 
Table 1. Podpis do tabeli

\begin{tabular}{|c|c|c|c|}
\hline Reference & $\begin{array}{l}\text { Aims (according } \\
\text { to the authors) }\end{array}$ & $\begin{array}{l}\text { Cited/months } \\
\text { available online }\end{array}$ & $\begin{array}{l}\text { Comments/type } \\
\text { of study }\end{array}$ \\
\hline$[4]$ & $\begin{array}{l}\text { Influence of professionals' attitude } \\
\text { for better patient self-management }\end{array}$ & $29 / 25$ & qualitative study \\
\hline$[5]$ & $\begin{array}{c}\text { Effectiveness and quality (completeness od data) } \\
\text { of eHealth tool vs standardised, } \\
\text { opportunistic recruitment }\end{array}$ & $19 / 36$ & $\begin{array}{l}\text { cluster } \\
\text { randomised } \\
\text { controlled trial }\end{array}$ \\
\hline$[6]$ & $\begin{array}{l}\text { Adherence of life-style intervention } \\
\text { along with economic evaluation }\end{array}$ & $5 / 13$ & $\begin{array}{l}\text { randomized con- } \\
\text { trolled pilot trial }\end{array}$ \\
\hline$[7]$ & Adherence of life-style intervention & $8 / 24$ & $\begin{array}{l}\text { randomized } \\
\text { controlled trial }\end{array}$ \\
\hline$[8]$ & Safety of eHealth based intervention & $5 / 20$ & meta-review \\
\hline$[10]$ & $\begin{array}{l}\text { Addressing challenges experience } \\
\text { by people with morbidity }\end{array}$ & $2 / 14$ & $\begin{array}{l}\text { qualitative } \\
\text { study }\end{array}$ \\
\hline$[11]$ & Patients' empowerments implication on MDs & $8 / 9$ & qualitative \\
\hline$[12]$ & Dimensions of patient engagement & $74 / 34$ & review \\
\hline$[13]$ & $\begin{array}{l}\text { Interactions between patient } \\
\text { and health care provider based on internet } \\
\text { information, and ethical care. }\end{array}$ & $34 / 40$ & $\begin{array}{l}\text { quality } \\
\text { study }\end{array}$ \\
\hline$[14]$ & $\begin{array}{c}\text { Electronic health record } \\
\text { - access influence of expectancy } \\
\text { of performance }\end{array}$ & $36 / 37$ & questionnaire \\
\hline$[15]$ & Reason of dropouts of eHealth intervention & $14 / 17$ & qualitative \\
\hline$[16]$ & $\begin{array}{l}\text { Compliance level using } \\
\text { eHealth solution for MI patients }\end{array}$ & $23 / 26$ & $\begin{array}{l}\text { randomised } \\
\text { controlled trial }\end{array}$ \\
\hline
\end{tabular}




\begin{tabular}{|c|c|c|c|}
\hline [17] & Efficacy of crowdfunding for eHealth project & $4 / 0$ & case study \\
\hline$[18]$ & $\begin{array}{l}\text { Evaluate critical incidents while } \\
\text { using e-health solution (patients' portal) }\end{array}$ & $15 / 29$ & qualitative \\
\hline [19] & $\begin{array}{l}\text { Evaluation of the quality } \\
\text { of web-communication vs direct meeting }\end{array}$ & $5 / 11$ & $\begin{array}{l}\text { qualitative, } \\
\text { experimental }\end{array}$ \\
\hline$[20]$ & Cost-utility and reach of eHealth solution & $6 / 21$ & research protocol \\
\hline [21] & $\begin{array}{l}\text { Collecting data decrease patients } \\
\text { with undiagnosed } \mathrm{FH}\end{array}$ & $39 / 22$ & $\begin{array}{l}\text { research } \\
\text { protocol }\end{array}$ \\
\hline [22] & $\begin{array}{l}\text { Assess of possible empowering patients } \\
\text { thanks to eHealth solution }\end{array}$ & $13 / 38$ & $\begin{array}{l}\text { multicentre and } \\
\text { multitask research }\end{array}$ \\
\hline [23] & $\begin{array}{l}\text { Validate eHEALS questionnaire as } \\
\text { a measure of eHealth literacy skills }\end{array}$ & $16 / 12$ & $\begin{array}{l}\text { comparative } \\
\text { study }\end{array}$ \\
\hline [24] & $\begin{array}{l}\text { Validate the smartphone application as the } \\
\text { diagnostic tool - way of assuring good data quality }\end{array}$ & $2 / 24$ & $\begin{array}{l}\text { qualitative } \\
\text { study }\end{array}$ \\
\hline [25] & $\begin{array}{l}\text { Effectiveness of eHealth intervention } \\
\text { - impact on behaviour }\end{array}$ & $3 / 21$ & $\begin{array}{l}\text { comparative cross- } \\
\text {-sectional study }\end{array}$ \\
\hline [26] & $\begin{array}{l}\text { Examine the experience of using } \\
\text { eHealth solution for gathering patient } \\
\text { - generated data in outpatient clinics }\end{array}$ & $15 / 23$ & $\begin{array}{l}\text { qualitative } \\
\text { study }\end{array}$ \\
\hline [27] & $\begin{array}{l}\text { Comparison of patients' expectation of eHealth } \\
\text { solution for disease control and self-management }\end{array}$ & $21 / 28$ & $\begin{array}{l}\text { quality } \\
\text { - focus group }\end{array}$ \\
\hline [28] & $\begin{array}{l}\text { Assess impact of eHealth solution } \\
\text { on lifestyle intervention }\end{array}$ & $2 / 5$ & $\begin{array}{l}\text { randomized } \\
\text { control trial }\end{array}$ \\
\hline [29] & $\begin{array}{l}\text { Efficacy of eHealth technology } \\
\text { used in managing rare disease }\end{array}$ & $2 / 3$ & $\begin{array}{l}\text { systematic } \\
\text { review }\end{array}$ \\
\hline [30] & $\begin{array}{l}\text { The role of eHealth solution in } \\
\text { patients' empowerment process }\end{array}$ & $2 / 5$ & review \\
\hline [31] & $\begin{array}{l}\text { eHealth tool effectively used } \\
\text { for integrating healthcare }\end{array}$ & $1 / 17$ & $\begin{array}{c}\text { planned } \\
\text { / controlled trial }\end{array}$ \\
\hline
\end{tabular}




\section{Patient - provider communication process}

In many countries patient-oriented care became the new goal of the both public and private healthcare providers. Specifically, one of the most important values to patients is a so-called "good communication" with health care providers. We know intuitively that this element of patient-oriented care could be possibly facilitated by ICT tools. The question whether implementing such ICT solutions is reasonable. It was proved that this aim is nearly impossible to achieve without an appropriate engagement of healthcare providers [30].

\section{Treatment and rehabilitation}

Organising home-based care can be difficult due to logistics, possible costs and obstacles to quality supervision at the same time. In this field, telemedicine became an accepted solution which facilitates the healthcare process while keeping cost under control. There are numerous examples of successful implementations of such projects $[6,9,16,20]$. Parallel to their achievements, there is a constant need to evaluate the new solutions. Technologies can replace some of the problems related to the so-called "human factor" and improve work [5, 24]. However Black et al. indicated that there is gap between the postulated benefits and the expectations of ICT solutions. The future eHealth technologies need evaluation [32]. Of the numerous studies published so far, only two systematic reviews on eHealth and two on mHealth were validated by
Cochrane Groups [33-35]. One of the emerging challenges is the quality of introducing and management of health information system, which requires basic technological knowledge from both the managerial and non-managerial staff. Moreover, systematic evaluation and interpersonal abilities engage more personnel.

\section{Conslusions}

Though eHealth obviously involves technology, the attitude of healthcare providers, payers, regulators and representatives of healthcare professionals looking to implement such solutions should be holistic and not merely technologically and economically focused [36]. Economic evaluation of any eHealth technology is still evolving and therefore needs standardization. While the evaluation of pharmaceutical substance can be easily based on randomized control trial, in the field of eHealth it is more complex and thus demanding [37].

The most important part of research assessing the implementation of an e-solution in any healthcare organisation is to clearly define the aim [38].

Summarizing, we currently face the rapid increase of the reports on eHealth solutions. The process of planning further projects in this field should be preceded by a careful revision of current achievements. It would be more beneficial if future studies address real problems of healthcare.

This review revealed that most of studies about eHealth attempted to assess more than one problem.

\section{References}

1. Olsson S, Lymberis A, Whitehouse D. European Commission activities in eHealth*. Int J Circumpolar Health [Internet]. 2004;63(4):310-6. Available from: https://doi.org/10.3402/ijch.v63i4.17747

2. A guide to ICT-related activities in Horizon 2020 Work Programme 2018-20 | Digital Single Market [Internet]. [cited 2019 May 7]. Available from: https://ec.europa.eu/digital-single-market/en/news/guide-ict-related-activities-horizon-2020-work-programme-2018-20

3. Fatehi F, Smith AC, Maeder A, Wade V, Gray LC. How to formulate research questions and design studies for telehealth assessment and evaluation. J Telemed Telecare [Internet]. 2017;23(9):759-63. Available from: https://journals.sagepub. com/doi/pdf/10.1177/1357633X16673274

4. Graffigna G, Barello S, Bonanomi A, Menichetti J. The Motivating Function of Healthcare Professional in eHealth and mHealth Interventions for Type 2 Diabetes Patients and the Mediating Role of Patient Engagement. J Diabetes Res [Internet]. 2016;2016:1-10. Available from: https://www.hindawi.com/journals/idr/2016/2974521/abs/

5. Mastellos N, Andreasson A, Huckvale K, Larsen M, Curcin V, Car J, et al. A cluster randomised controlled trial evaluating the effectiveness of eHealth-supported patient recruitment in primary care research: the TRANSFoRm study protocol. Implement Sci IS [Internet]. 2015;10(15):1-7. Available from: https://www.ncbi.nlm.nih.gov/pubmed/25648301

6. Redman LM, Gilmore LA, Breaux J, Thomas DM, Elkind-Hirsch K, Stewart T, et al. Effectiveness of SmartMoms, a Novel eHealth Intervention for Management of Gestational Weight Gain: Randomized Controlled Pilot Trial. JMIR Mhealth Uhealth [Internet]. 2017;5(9):e133. Available from: http://mhealth.jmir.org/2017/9/e133/ 
7. Van Dyck D, Plaete J, Cardon G, Crombez G, De Bourdeaudhuij I. Effectiveness of the self-regulation eHealth intervention 'MyPlan1.0.' on physical activity levels of recently retired Belgian adults: a randomized controlled trial. Health Educ Res [Internet]. 2016 Jul 15;31(5):653-64. Available from: https://doi.org/10.1093/her/cyw036

8. O'Donnell H, Pagliari C, Finucane A. P-43 Evaluation of opiate prescribing and adjustment in renal impairment in an acute medical admissions unit. BMJ Support Palliat Care [Internet]. 2017 Mar 1 [cited 2019 May 7];7(Suppl 1):A16. Available from: https://search.proquest.com/openview/262b1e9d209ec4436c49f2c2e018075e/1?pq-origsite=gscholar \&cbl=2040968

9. Carlsen K, Houen G, Jakobsen C, Kallemose T, Paerregaard A, Riis LB, et al. Individualized Infliximab Treatment Guided by Patient-managed eHealth in Children and Adolescents with Inflammatory Bowel Disease. Inflamm Bowel Dis [Internet]. 2017 Jun 14;23(9):1473-82. Available from: https://doi.org/10.1097/MIB.0000000000001170

10. Runz-Jørgensen SM, Schiøtz ML, Christensen U. Perceived Value of eHealth among People Living with Multimorbidity: A Qualitative Study. J Comorbidity [Internet]. 2017;7(1):96-111. Available from: https://doi.org/10.15256/joc.2017.7.98

11. Grünloh C, Myreteg G, Cajander Å, Rexhepi H. "Why Do They Need to Check Me?” Patient Participation Through eHealth and the Doctor-Patient Relationship: Qualitative Study. J Med Internet Res [Internet]. 2018;20(1):e11. Available from: http://www.jmir.org/2018/1/e11/

12. Barello S, Triberti S, Graffigna G, Libreri C, Serino S, Hibbard J, et al. eHealth for Patient Engagement: A Systematic Review. Front Psychol [Internet]. 2016;6:2013. Available from: https://www.frontiersin.org/article/10.3389/fpsyg.2015.02013

13. Townsend A, Leese J, Adam P, McDonald M, Li LC, Kerr S, et al. eHealth, Participatory Medicine, and Ethical Care: A Focus Group Study of Patients' and Health Care Providers' Use of Health-Related Internet Information. J Med Internet Res [Internet]. 2015;17(6):e155. Available from: http://www.jmir.org/2015/6/e155/

14. Tavares J, Oliveira T. Electronic Health Record Patient Portal Adoption by Health Care Consumers: An Acceptance Model and Survey. J Med Internet Res [Internet]. 2016;18(3):e49. Available from: http://www.jmir.org/2016/3/e49/

15. Lie SS, Karlsen B, Oord ER, Graue M, Oftedal B. Dropout From an eHealth Intervention for Adults With Type 2 Diabetes: A Qualitative Study. J Med Internet Res [Internet]. 2017;19(5):e187. Available from: http://www.jmir.org/2017/5/e187/

16. Johnston N, Bodegard J, Jerström S, Åkesson J, Brorsson H, Alfredsson J, et al. Effects of interactive patient smartphone support app on drug adherence and lifestyle changes in myocardial infarction patients: A randomized study. Am Heart J [Internet]. 2016 Aug 1 [cited 2019 May 7];178:85-94. Available from: https://www.sciencedirect.com/science/article/pii/ $\underline{\mathrm{S} 000287031630062 \mathrm{X}}$

17. Koole MAC, Kauw D, Winter MM, Schuuring MJ. A successful crowdfunding project for eHealth research on grown-up congenital heart disease patients. Int J Cardiol [Internet]. 2018;273:96-9. Available from: http://www.sciencedirect.com/ science/article/pii/S016752731831355X

18. Alpert JM, Krist AH, Aycock RA, Kreps GL. Applying Multiple Methods to Comprehensively Evaluate a Patient Portal's Effectiveness to Convey Information to Patients. J Med Internet Res [Internet]. 2016;18(5):e112. Available from: http://www. imir.org/2016/5/e112/

19. Tates K, Antheunis ML, Kanters S, Nieboer TE, Gerritse MBE. The Effect of Screen-to-Screen Versus Face-to-Face Consultation on Doctor-Patient Communication: An Experimental Study with Simulated Patients. J Med Internet Res [Internet]. 2017;19(12):e421. Available from: http://www.jmir.org/2017/12/e421/

20. van der Hout A, van Uden-Kraan CF, Witte BI, Coupé VMH, Jansen F, Leemans CR, et al. Efficacy, cost-utility and reach of an eHealth self-management application 'Oncokompas' that helps cancer survivors to obtain optimal supportive care: study protocol for a randomised controlled trial. Trials [Internet]. 2017;18(1):228. Available from: https://doi.org/10.1186/ s13063-017-1952-1

21. Vallejo-Vaz AJ, Akram A, Kondapally Seshasai SR, Cole D, Watts GF, Hovingh GK, et al. Pooling and expanding registries of familial hypercholesterolaemia to assess gaps in care and improve disease management and outcomes: Rationale and design of the global EAS Familial Hypercholesterolaemia Studies Collaboration. Atheroscler Suppl [Internet]. 2016;22:1-32. Available from: http://www.sciencedirect.com/science/article/pii/S1567568816300496

22. Lettieri E, Fumagalli LP, Radaelli G, Bertele' P, Vogt J, Hammerschmidt R, et al. Empowering patients through eHealth: a case report of a pan-European project. BMC Health Serv Res [Internet]. 2015;15(1):309. Available from: https://doi. org/10.1186/s12913-015-0983-0

23. Paige SR, Krieger JL, Stellefson M, Alber JM. eHealth literacy in chronic disease patients: An item response theory analysis of the eHealth literacy scale (eHEALS). Patient Educ Couns [Internet]. 2017;100(2):320-6. Available from: http://www. sciencedirect.com/science/article/pii/S0738399116304189

24. Kueppers S, Daskalopoulos I, Jha A, Fragopanagos NF, Kassavetis P, Nomikou E, et al. From Wellness to Medical Diagnostic Apps: The Parkinson's Disease Case BT - eHealth $360^{\circ}$. In: Giokas K, Bokor L, Hopfgartner F, editors. Cham: Springer International Publishing; 2017. p. 384-9. 
25. Coorey GM, Neubeck L, Usherwood T, Peiris D, Parker S, Lau AYS, et al. Implementation of a consumer-focused eHealth intervention for people with moderate-to-high cardiovascular disease risk: protocol for a mixed-methods process evaluation. BMJ Open [Internet]. 2017 Jan 1;7(1):e014353. Available from: http://bmjopen.bmj.com/content/7/1/e014353.abstract

26. Cohen DJ, Keller SR, Hayes GR, Dorr DA, Ash JS, Sittig DF. Integrating Patient-Generated Health Data Into Clinical Care Settings or Clinical Decision-Making: Lessons Learned From Project HealthDesign. JMIR Hum Factors [Internet]. 2016;3(2):e26. Available from: http://humanfactors.jmir.org/2016/2/e26/

27. Huygens MWJ, Vermeulen J, Swinkels ICS, Friele RD, van Schayck OCP, de Witte LP. Expectations and needs of patients with a chronic disease toward self-management and eHealth for self-management purposes. BMC Health Serv Res [Internet]. 2016;16(1):232. Available from: https://doi.org/10.1186/s12913-016-1484-5

28. Parker SM, Stocks N, Nutbeam D, Thomas L, Denney-Wilson E, Zwar N, et al. Preventing chronic disease in patients with low health literacy using eHealth and teamwork in primary healthcare: protocol for a cluster randomised controlled trial. BMJ Open [Internet]. 2018 Jun 1;8(6):e023239. Available from: http://bmjopen.bmj.com/content/8/6/e023239.abstract

29. Badawy SM, Cronin RM, Hankins J, Crosby L, DeBaun M, Thompson AA, et al. Patient-Centered eHealth Interventions for Children, Adolescents, and Adults With Sickle Cell Disease: Systematic Review. J Med Internet Res [Internet]. 2018;20(7):e10940. Available from: http://www.jmir.org/2018/7/e10940/

30. Ammenwerth E. From eHealth to ePatient: The Role of Patient Portals in Fostering Patient Empowerment. EJBI [Internet]. 2018;14(2):20-3. Available from: https://www.ejbi.org/downloads/EJBI 2 2018.pdf\#page=24

31. Saillour-Glénisson F, Duhamel S, Fourneyron E, Huiart L, Joseph JP, Langlois E, et al. Protocole of a controlled before-after evaluation of a national health information technology-based program to improve healthcare coordination and access to information. BMC Health Serv Res [Internet]. 2017;17(1):297. Available from: https://doi.org/10.1186/s12913-017-2199-y

32. Black AD, Car J, Pagliari C, Anandan C, Cresswell K, Bokun T, et al. The Impact of eHealth on the Quality and Safety of Health Care: A Systematic Overview. PLOS Med [Internet]. 2011 Jan 18;8(1):e1000387. Available from: https://doi.org/10.1371/ journal.pmed.1000387

33. Thabrew H, Stasiak K, Hetrick SE, Wong S, Huss JH, Merry SN. E-Health interventions for anxiety and depression in children and adolescents with long-term physical conditions [Internet]. Cochrane Database of Systematic Reviews. 2018. Available from: http://doi.wiley.com/10.1002/14651858.CD012489.pub2

34. Smith C, Gold J, Ngo TD, Sumpter C, Free C. Mobile phone-based interventions for improving contraception use [Internet]. Cochrane Database of Systematic Reviews. 2015. Available from: http://doi.wiley.com/10.1002/14651858.CD011159.pub2

35. de Jongh T, Gurol-Urganci I, Vodopivec-Jamsek V, Car J, Atun R. Mobile phone messaging for facilitating self-management of long-term illnesses. Cochrane Database Syst Rev [Internet]. 2012;(12). Available from: https://doi.org//10.1002/14651858. CD007459.pub2

36. Sligo J, Gauld R, Roberts V, Villa L. A literature review for large-scale health information system project planning, implementation and evaluation. Int J Med Inform [Internet]. 2017;97:86-97. Available from: http://www.sciencedirect.com/ science/article/pii/S1386505616302003

37. Sanyal C, Stolee P, Juzwishin D, Husereau D. Economic evaluations of eHealth technologies: A systematic review. PLoS One [Internet]. 2018 Jun 13;13(6):e0198112. Available from: https://doi.org/10.1371/journal.pone.0198112

38. van Gemert-Pijnen JEWC, Nijland N, van Limburg M, Ossebaard HC, Kelders SM, Eysenbach G, et al. A Holistic Framework to Improve the Uptake and Impact of eHealth Technologies. J Med Internet Res [Internet]. 2011;13(4):e111. Available from: http://www.jmir.org/2011/4/e111/ 